\title{
A Survey on the Aromatic Plants of Libya
}

\section{Najat Agiel ${ }^{1,2}$, Filiz Mericli ${ }^{*}$}

${ }^{1}$ Near East University, Faculty of Pharmacy, Department of Pharmacognosy, Nicosia - Northern CYPRUS. ${ }^{2}$ University of Tripoli, Faculty of Education, Department of Biology, LIBYA.

\begin{abstract}
Objectives: The aim of this study is to investigate on some aromatic plants growing in Libya, their major volatile oils contents and traditional uses, indicating dangerous hazards facing plant biodiversity especially medicinal plants and measures taken to protect them. Methods: The study is mainly based on electronic database survey using Scopus, PubMed, and Science Direct, etc. and communication with Libyan local inhabitants of some areas. Gathered information has been evaluated and summarized in tables. Results: Aromatic plant of 41 species has been mentioned of medicinal value represented by 14 plant families and 29 genera. Three aromatic plant species growing in Libya are not recognized and used by Libyans. Endemic species are mentioned; Origanum cyrenaicum, Teucrium zononii and Ballota andreuzziana. Conclusions: Even though Libya remains as one of the most biologically diverse countries in the Mediterranean region, scarce information about aromatic medicinal plants could be found. Libya is also suffering from extreme biodiversity destruction and degradation due to Sahara expenses and climate changes and other reasons. To deal with the problem IUCN Centre for Mediterranean Cooperation has made a mission in Libya to promote projects.
\end{abstract}

Keywords: Aromatic Plants, Volatile Oils, Traditional Uses, Endemic Species, IUCN Missions.

\section{INTRODUCTION}

Libya is a country in the Maghreb region of North Africa. It has an area of 1760000 square kilometres consisting mainly of desert (more than 90\%) and the Mediterranean coast. Coastal strip and El-Jabal El-Akhdar known as the green mountain region which contributes to about $50 \%$ of the total plants in the whole country. ${ }^{1,2}$ While other percentage of plants are distributed in regions as the El- Jabel El Garbi (Gharian), Ghadames, Awbari and Tarhona regions. There are 2103 plant species in Libya that belong to 856 genera and 155 families. $^{2}$ According to literature there are 450 medicinal plants growing in Libya and 208 are recognized and extensively used by Bedouins and local inhabitants in traditional medicine. ${ }^{3-5}$ Where about $30 \%$ of the population in Libya relies on traditional medicine. ${ }^{6,7}$ Although there has been no detailed ethnopharmacological investigation in Libya, aromatic plants are used for treatment of diseases and also in perfumery and cosmetics. Thus the main aim of this investigation is to highlight on some aromatic plant species growing in Libya and their traditional uses. Taking into account that the medicinal plants from Libyan flora is still insufficiently investigated, and the scarce information about the Libyan folkloric medicine especially aromatic plants, this will be the useful review that is carried out on the topic.

\section{MATERIAL AND METHODS}

This review is mainly based on communication with some Libyan people using traditional medicines and electronic database survey using Scopus, PubMed, Science Direct and Google Scholar. Gathered information has been evaluated and summarized in Tables.

\section{RESULTS AND DISCUSSION.}

According to the literature survey 41 aromatic plants grown widely in Libya are represented
DOI: 10.5530/ijper.51.3s.35 Correspondence: Filiz Mericli,

Near East University, Faculty Of Pharmacy, Department Of Pharmacognosy, Nicosia Northern CYPRUS.

Contact: +90 392 6802000/123 E-mail: filiz.mericli@neu. edu.tr 


\begin{tabular}{|c|c|c|c|c|}
\hline $\begin{array}{l}\text { Plant name } \\
\text { (Family) }\end{array}$ & $\begin{array}{l}\text { Local name usage } \\
\text { part }\end{array}$ & Traditional medicinal Uses & Major compounds & Ref. \\
\hline $\begin{array}{l}\text { Pistacia atlantica Desf } \\
\text { Anacardiaceae. }\end{array}$ & Batum Leaves & $\begin{array}{l}\text { It is chewed against respiratory } \\
\text { affections. }\end{array}$ & $\begin{array}{l}\text { Terpinene-4-ol, D- } \\
\text { germacrene }\end{array}$ & 8,14 \\
\hline $\begin{array}{l}\text { Carum carvi } L . \\
\text { Apiaceae }\end{array}$ & Krweia & Carminative and lactagogue. & & 9 \\
\hline $\begin{array}{c}\text { Coriandrum sativum } \mathrm{L} . \\
\text { Apiaceae }\end{array}$ & Kusber & $\begin{array}{l}\text { Lactagogue,, carminative. } \\
\text { cardiotonic }\end{array}$ & & 9 \\
\hline $\begin{array}{c}\text { Pimpinella anisum L. } \\
\text { Apiaceae }\end{array}$ & Camun & $\begin{array}{l}\text { Tranquilizer, spasmolytic, cough, } \\
\text { tonic, diuretic, digestive, increase } \\
\text { uterine contractility and lactagogue. }\end{array}$ & & 9 \\
\hline $\begin{array}{l}\text { Artemisia absinthium } \\
\text { L. Asteraceace }\end{array}$ & Amna- Maryam & $\begin{array}{l}\text { Enhance uterine contractility, skin } \\
\text { ulcers, kidney stones. }\end{array}$ & & 9 \\
\hline $\begin{array}{l}\text { Chamomilla pubescens (Desf) } \\
\text { Alavi Chamomilla aurea Loefl. } \\
\text { Asteraceace }\end{array}$ & Falyia & $\begin{array}{l}\text { GIT disorders (flatulence, gastritis), } \\
\text { skin diseases (dermatitis), } \\
\text { menstruation colic, diuretic urinary } \\
\text { tract infection, expectorant, for } \\
\text { laryngitis, sinusitis, cracks of feet and } \\
\text { hands, and asthma. }\end{array}$ & & 10,8 \\
\hline $\begin{array}{c}\text { Commiphora myrrha (Nees) Engl. } \\
\text { Burseraceace }\end{array}$ & Al-morr & $\begin{array}{l}\text { Anti-inflammatory, expectorant, } \\
\text { antiseptic, emenagogue and } \\
\text { vulnerary. }\end{array}$ & & 9 \\
\hline $\begin{array}{l}\text { Cupressus sempervirens } L \\
\text { Cupressaceae }\end{array}$ & Al-sarow & Cough and heart diseases. & & 8 \\
\hline $\begin{array}{l}\text { Juniperus communis L. } \\
\text { Juniperus phoenicea L. } \\
\text { Cupressaceae }\end{array}$ & Arar Leaves & Gastritis. & $\begin{array}{l}\alpha \text {-pinene, myrcene, } \\
\text { and } \beta \text {-phellandrene }\end{array}$ & 9,14 \\
\hline $\begin{array}{c}\text { Retama raetam Forssk } \\
\text { Fabaceae }\end{array}$ & Al- ratem Shoot & Diabetes, sinusitis and antitumor & Linalool, limonene & 10,16 \\
\hline $\begin{array}{c}\text { Pelargonium odoratissimum L. } \\
\text { Geraniaceae }\end{array}$ & Al-ather Al-arabi & Antidabetic & & $\mathrm{OC}$ \\
\hline $\begin{array}{c}\text { Ajuga iva(L.) Schreb. } \\
\text { Lamiaceae }\end{array}$ & Chendagora Shoot & $\begin{array}{c}\text { Gastritis, vomiting, diarrhoea, gastric } \\
\text { ulcer, anthelminthic, anti-diabetic, } \\
\text { pulmonary disorders }\end{array}$ & Carvacrol & $10,8,12$ \\
\hline $\begin{array}{c}\text { Ballota andreuzziana Pamp. } \\
\text { (Endemic ) } \\
\text { Lamiaceae }\end{array}$ & Flower buds & & Caryophylline & 13 \\
\hline $\begin{array}{l}\text { Lavandula multifida L. } \\
\text { Lamiaceae }\end{array}$ & Al-kuzami & $\begin{array}{l}\text { Externally: antiseptic for wounds } \\
\text { Internally: CNS disorders (stress, } \\
\text { depression, headache), anti- } \\
\text { rheumatic, asthma, diuretic and for } \\
\text { gastritis. }\end{array}$ & & 9 \\
\hline $\begin{array}{l}\text { Marrubium vulgare } \mathrm{L} . \\
\text { Marrubium alysson } \mathrm{L} . \\
\text { Lamiaceae }\end{array}$ & Rubia Arial parts & $\begin{array}{c}\text { For rheumatism, antidiabetic, } \\
\text { expectorant and analgesic for joint } \\
\text { pains. }\end{array}$ & $\begin{array}{c}\text { Caryophyllene, cineole, } \\
\text { thymol }\end{array}$ & $8,9,12$ \\
\hline $\begin{array}{l}\text { Mentha piperita L. } \\
\text { Lamiaceae }\end{array}$ & Nanah & $\begin{array}{l}\text { Externally: infected wounds and } \\
\text { gargle. Internally: spasmolytic, } \\
\text { carminative, uterine relaxant, tonic } \\
\text { and antinociceptive. }\end{array}$ & & 11 \\
\hline $\begin{array}{l}\text { Ocimum basilicum L. } \\
\text { Lamiaceae }\end{array}$ & Habak Leaves & $\begin{array}{c}\text { Stomachic, spasmolytic and } \\
\text { carminative. }\end{array}$ & & 11 \\
\hline
\end{tabular}




\begin{tabular}{|c|c|c|c|c|}
\hline $\begin{array}{l}\text { Plant name } \\
\text { (Family) }\end{array}$ & $\begin{array}{l}\text { Local name usage } \\
\text { part }\end{array}$ & Traditional medicinal Uses & Major compounds & Ref. \\
\hline $\begin{array}{c}\text { Origanum majorana L. } \\
\text { Origanum vulgare } \mathrm{L} . \\
\text { Origanum cyrenaicum Beg.\&Vacc. } \\
\text { (endemic) } \\
\text { Lamiaceae }\end{array}$ & $\begin{array}{l}\text { Martwosha } \\
\text { Arial parts }\end{array}$ & $\begin{array}{l}\text { Externally: inhale crushed leaves } \\
\text { during flu to facilitate breathing. } \\
\text { Also for ear congestion. Internally: } \\
\text { Expectorant, carminative, stomachic } \\
\text { and for menstrual cramps. Against } \\
\text { dysentery. }\end{array}$ & $\begin{array}{l}\text { Terpinol, geraniol, } \\
\text { eugenol, linalool }\end{array}$ & $6,11,15$ \\
\hline $\begin{array}{l}\text { Rosmarinus officinalis } \mathrm{L} . \\
\text { Lamiaceae }\end{array}$ & $\begin{array}{l}\text { Kelli Leaves and } \\
\text { flowers }\end{array}$ & $\begin{array}{c}\text { Externally: Skin cleanser, } \\
\text { conjunctivitisand gargle in throat } \\
\text { infections and voice cracks. } \\
\text { Internally: Anti rheumatic, stomachic, } \\
\text { nervous stimulant, menstrual cramps } \\
\text { and gallbladder disorders. }\end{array}$ & Cineol & $6,11,12$ \\
\hline $\begin{array}{l}\text { Salvia aegyptiaca } \mathrm{L} . \\
\text { Salvia fruticosa } \mathrm{L} . \\
\text { Salvia officinalis } \mathrm{L} . \\
\quad \text { Lamiaceae }\end{array}$ & $\begin{array}{l}\text { Tefah El-Shahi } \\
\text { Aerial parts }\end{array}$ & $\begin{array}{l}\text { Digestive, drowsiness, nervousness, } \\
\text { headache, and anti-diabetic. }\end{array}$ & $\begin{array}{l}\text { Aristolene, myrcene } \\
\text { and cymene }\end{array}$ & $\begin{array}{c}6,9,17 \\
18\end{array}$ \\
\hline $\begin{array}{l}\text { Satureja thymbra L } \\
\text { Lamiaceae }\end{array}$ & Aerial parts & & $\begin{array}{l}\mathrm{y} \text {-terpinene, thymol, } \\
\mathrm{p} \text {-cymene, carvacrol }\end{array}$ & 19,24 \\
\hline $\begin{array}{c}\text { Thymus capitatus L. (Hoffm. \&Link). } \\
\text { Thymus serpyllum L. } \\
\text { Thymus vulgaris L. } \\
\text { Thymus algeriensis Boiss. } \\
\text { Lamiaceae }\end{array}$ & Zather Leaves & $\begin{array}{l}\text { Externally:Gargle, for throat and gum } \\
\text { inflammation. Internally:Cough(chest } \\
\text { infections and expectorant), } \\
\text { gastroenteritis, anthelmintic, cardio } \\
\text { tonic and spasmolytic. }\end{array}$ & Thymol and carvacrol & $\begin{array}{c}8,12 \\
21\end{array}$ \\
\hline $\begin{array}{c}\text { Tercrium polium L. } \\
\text { Teucrium apollinis Maire\&Weiller } \\
\text { Teucrium zononii Pamp.(Endemic) } \\
\text { Lamiaceae }\end{array}$ & Jada & $\begin{array}{l}\text { Antidiabetic, antihypertensive and for } \\
\text { extruding kidney stones. }\end{array}$ & D- germacrene & $\begin{array}{c}9,13 \\
22\end{array}$ \\
\hline $\begin{array}{l}\text { Cymbopgon shoenanthus (L.) } \\
\text { Spreng. } \\
\text { Poaceace }\end{array}$ & Edkar & $\begin{array}{l}\text { Spasmolytic (especially children), } \\
\text { menstrual pain and anti-rheumatic. }\end{array}$ & & 9 \\
\hline $\begin{array}{l}\text { Rosa damascena Mill. } \\
\text { Rosaceace }\end{array}$ & Al- ward & $\begin{array}{l}\text { The seed decoction is used against } \\
\text { fevers and headaches or externally } \\
\text { applied to cure trachoma, and hair } \\
\text { loss. }\end{array}$ & & 8,9 \\
\hline $\begin{array}{l}\text { Ruta graveolens L. } \\
\quad \text { Rutaceace }\end{array}$ & Fagal & $\begin{array}{l}\text { Migraine and compresses for } \\
\text { tried eyes. Aerial part used } \\
\text { against rheumatic infections and } \\
\text { ecchymosis. }\end{array}$ & & 11,8 \\
\hline $\begin{array}{l}\text { Salvadora persica Wallich, } \\
\text { Salvadoraceae }\end{array}$ & Swak Leaves & $\begin{array}{l}\text { Chewing sticks used for tooth } \\
\text { cleaning and polishing. }\end{array}$ & $\begin{array}{l}\text { Cineol,caryophyllene, } \\
\text { caryophyllene xide }\end{array}$ & 6,14 \\
\hline $\begin{array}{l}\text { Solanum nigrum L. } \\
\quad \text { Solanaceace }\end{array}$ & $\begin{array}{l}\text { Enab -Al-deib } \\
\text { Fruits and leaves }\end{array}$ & $\begin{array}{c}\text { Liver diseases, diuretic, constipation, } \\
\text { dermatitis, arthritis, rheumatic, } \\
\text { hypertension. }\end{array}$ & Thymol & $\begin{array}{l}11 \\
10 \\
20\end{array}$ \\
\hline $\begin{array}{l}\text { Verbena tenuisecta Briq. } \\
\text { Verbenaceae }\end{array}$ & Flower buds & & Limonene & 13 \\
\hline
\end{tabular}

by 14 plant families and 29 genus. Only 18 species were investigated for their essential oil constituents. The endemic plants Origanum cyrenaicum, Teucrium zononii and Ballota andreuzziana need further investigation. Three species (Ballota andrenzziana, Satureja thymbra, Verbena tenuisecta) are not used in Libyan Folkloric medicine.
Although two species (Satureja thymbra, Verbena tenuisecta) growing widely in Libya are used all over the world, but not used in Libya. ${ }^{24}$ On the other hand Libya is also suffering from extreme biodiversity destruction and degradation due to Sahara expenses and climate changes and other reasons. To deal with the problem IUCN 
Centre for Mediterranean Cooperation has made a mission in Libya to promote projects. For this purpose 2 projects were organized by Small Initiatives for Civil Society Organizations in North Africa (PPI-OSCAN) funded by the French Global Environment Facility (FGEF) and the MAVA Foundation and Critical Ecosystem Partnership Fund (CEPF): "Conservation project for endangered medicinal and aromatic plants in Msallata" and "Promoting the value of key biodiversity areas in North Africa through the involvement of civil society in their conservation and management'. In 2015 Tree Friends Association supported by the IUCN in frame work of PPI-OSCAN, started the project 'The conservation of medicinal, aromatic and endangered plant species in Msallata at National Natural Reserve Park' at Al-saafeen area. The project aims for plant propagation especially medicinal and aromatic plants that are endangered, also greenhouse construction and target plants identified, collected and restricted as a second phase of the project. A map was prepared for redetermination of the geographical region borders of the park, pinpointing areas of target plants.

\section{CONCLUSION}

Further phytochemical investigations and documentation of aromatic plants used in traditional Libyan medicine should be carried out immediately. Aromatic plants suffer as well as other plant species in Libya from extreme bio-diversity destruction and degradation due to global climate change, overgrazing, uprooting, and wood cutting especially along the Libyan coast. ${ }^{23}$ The projects about the protection and propagation of plant biodiversity in particular medicinal and aromatic plants of Libya must be supported.

\section{ACKNOWLEDGMENTS}

The author Najat A. Agiel thankful to the Higher Institute of the Libyan Education and University of TripoliLibya for granting her the opportunity of scholarship at Near East University. We would also like to be grateful to Elmaki Ayad Elagil project coordinator and director of Nature Conservation Department Environment General Authority-Libya for his cooperation and valuable information.

\section{CONFLICT OF INTEREST STATEMENT}

The authors have no conflict of interest to declare.

\section{ABBREVIATION USED}

CEPF: The Critical Ecosytem Partnership Fund; FGEF: French Global Environment Facility; IUCN: International Union for Conservation of Nature; PPIOSCAN: Small Initiatives for Civil Society Organizations in North Africa.

\section{REFERENCES}

1. Boulos L. Our Present Knowledge of the Flora and Vegetation of Libya. Webbia. 1972;26:366-400.

2. Feng $\mathrm{Y}$, Lei J, Xu X, Pan B. Composition and characteristics of Libyan flora, Arch Biol Sci. 2013;65(2):651-7. DOI:10.2298/ABS1302651Y.

3. Vasisht K, Kumar V. Comendium of medicinal and aromatic plants. 2004;1 ICS-UNIDO, Italy.

4. Auzi A. Medicinal plants in Libya, Paper presented in "First Conference on Natural Resources", Sert, Libya (in Arabic).

5. El-Mokasabi MF. The State of the Art of Traditional Herbal Medicine in the Eastern Mediterranean Coastal Region of Libya Middle-East Journal of Scientific Research. 2014;21(4):575-82.

6. Kotb FT. Medicinal Plants in Libya, Arab Encyclopedia House, Beirut, Lebanon, 1985.

7. El-Gadi A, Bashaina SMA. Libyan Folk Medicine, Dar El-Hkima, Tripoli, Libya.1997.

8. De Antonino N, Antonino PA forgotten collection: the Libyan ethnobotanical exhibits (1912-14) by Trotter A, at the Museum O. Comes at the University Federico II in Naples, Italy, Journal of Ethnobiology and Ethnomedicine. 2012;8(1):4.

9. El- Gadi AA. Usage of some plants in Libyan Folk-medicine, part two 2nd ed. Dar Al-Hekma. Tripoli,1994.

10. El-Mokasabi MF. Floristic Composition and Traditional Uses of Plant Species at WadiAlkuf, Al-Jabal Al-Akhder, Libya, American-Eurasian J Agric \& Environ Sci. 2014;4(8):685-97.

11. El-Gadi A, Bshina SM. Usage of some plants in Libyan folk medicine. Part 1, Dar AlkutobAlwatania, Benghazi 1994.

12. El-Hawary S, EL-Shabrawy A, Ezzatl S, EL-Shibany F. Gas chromatographymass spectrometry analysis, hepatoprotective and antioxidant activities of the essential oils of four Libyan herbs. Journal of Medicinal Plants Research. 2013;7(24):1746-53

13. Abdelshafeeka AK, Elgattara AA, Zarkoona HA, Alwahashc AM, Shahatb AA. Investigation of the volatile oils, lipid constituents and biological activity of Ballota andreuzziana, Teucrium zanonii and Verbena tenuisecta in Libya, Asian Pacific Journal of Tropical Medicine 2010;3(8):594-60.

14. Garboui SS, Borg-Karlson AK, Palsson K. Tick Repellent Properties of Three Libyan Plants, Journal of Medical Entomology. 2009;46(6):1415-9. doi:http:// dx.doi.org/10.1603/033.046.0623.

15. Elabbar AF, EL-Barasi MY, ALawamy MWM. Seasonal variation study of the volatile oils of Origanum cyrenaicum in Libya, Pelagia Research Library Advances in Applied Science Research. 2014;5(1):39-42.

16. Awen ZB, Unnithan CR, Ravi S, Kermagy A, Sasikumar JM, Khrbash AS, Ekreem WL. Essential oils of Retama raetam from Libya: chemical composition and antimicrobial activity, Nat Prod Res. 2011;25(9):927-33.

17. Giweli AA, Džamić AM, Soković M, Ristić SM, Janaćković P, Marin DP. The chemical composition, antimicrobial and antioxidant activities of the essential oil of Salvia fruticosa growing wild in Libya, Arch Biol Sci.2011;65(1):321-9. doi:10.2298/abs1301321g.

18. Awen ZB, Unnithan RC, Ravi S, Kermagy A, Prabhu V, Hemlal H. Chemical Composition of Salvia officinalis Essential oil of Libya, Journal of Essential Oil Bearing Plants. 2011;14:1.

19. Giweli A, Džamić A, Soković M, Ristić M, Marin P. Antimicrobial and Antioxidant Activities of Essential Oils of Satureja thymbra Growing Wild in Libya. Molecules. 2012;17(5):4836-50.

20. Talal AA, Iman OM, Abdurazag AA, Hudaib MM. Volatile Oil Constituents of Fruits and Leaves of Solanum nigrum L. Growing in Libya, Journal of Essential Oil Bearing Plants, 2014;17(3):397-404. DOI:10.1080/097206 0X.2014.895194. 
21. Giweli A, Džamić A, Soković M, Ristić M, Marin P. Chemical composition, antioxidant and antimicrobial activities of essential oil of Thymus algeriensis wild-growing in Libya, Open Life Sciences. 2013;8(5):504-11, ISSN (Online) 2391-5412, DOI: 10.2478/s11535-013-0150-0.

22. Elabbara AF, Habelb AM, Bozkeh AMNM, El-Tuonsi MTA, Awina MT. The essential oil composition of Teucrium apollinis (Lamiaceae) from Libya, Der Chemica Sinica. 2014;5(1):26-7. ISSN: 0976-8505
23.

Louhaichi M, Salkini AK, Estita HE, Belkhir S. Initial Assessment of Medicina Plants Across the Libyan Mediterranean Coast, Advances in Environmental Biology. 2011;5(2):359-70. 2011 ISSN 1995-0756.

24. Askun T, Tumen G, Satıl F, karaaslan D. Active constituents of some Satureja species and their biological activities. African Journal of Microbiology Research. 2012;6(22):4623-33.

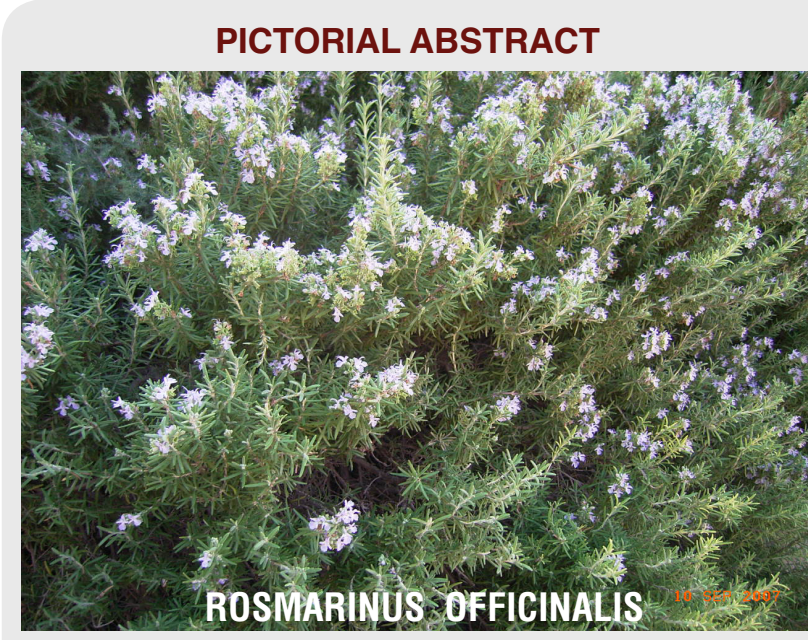

\section{SUMMARY}

- According to the our investigation 41 aromatic plants growing wildly in Libya are represented by 14 plant families and 29 genus.

- Amoung them only 18 species were investigated for their essential oil constituents.

- Three species (Ballota andreuzziana, Satureja thymbra, Verbena tenuisecta ) are not used in Libyan Folkloric medicine.

- Although two species (Satureja thymbra, Verbena tenuisecta) growing widely in Libya are used all over the world, but not used in Libya.

- The endemic plants Origanum cyrenaicum, Teucrium zononii and Ballota andreuzziana need further investigation.

\section{About Authors}

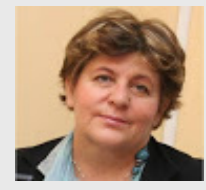

Prof.Dr.Filiz Meriçli: Gratuated Ankara University, Faculty of Pharmacy; she is working on active principles and biological activities of medicinal plants and also herbal medicines, medicinal teas and medicinal oils.

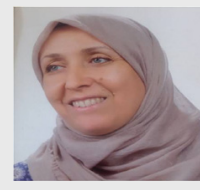

Najat Abubaker A. Agiel: Gratuated University of Tripoli, Faculty of Pharmacy (Libya) ; she is currently working on her PhD thesis project in Pharmacognosy Department at Near East University.

Cite this article: Agiel N, Mericli F. A Survey on the Aromatic Plants of Libya. Indian J of Pharmaceutical Education and Research. 2017;51(3)Suppl:S304-08. 